\title{
First records of the entomopathogenic fungus Ophiocordyceps variabilis (Petch) G.H. Sung, J.M. Sung, Hywel-Jones et Spatafora from Siberia
}

\section{Первые сведения об энтомопаразитическом грибе Opbiocordyceps variabilis (Petch) G.H. Sung, J.M. Sung, Hywel-Jones et Spatafora в Сибири}

\author{
O.N. Yaroslavtseva*, D.V. Ageev**, \\ T.M. Bulyonkova***, V.Yu. Kryukov* \\ О.Н. Ярославцева*, А.В. Агеев**, \\ Т.М. Бульонкова***, В.Ю. Крюков*
}

\footnotetext{
* Institute of Systematics and Ecology of Animals, Russian Academy of Sciences, Siberian Branch, Frunze Str. 11, Novosibirsk 630091 Russia. E-mail: yarosl@inbox.ru, krukoff@mail.ru.

* Институт систематики и экологии животных СО РАН, ул Фрунзе 11, Новосибирск 630091 Россия.

** Signatec Ltd., Inzhenernaya Str. 22, Novosibirsk 630090 Russia. E-mail: dim@diamondsteel.ru.

** ООО «СИГНАТЕК», ул. Инженерная 22, Новосибирск 630090 Россия.

*** A.P. Ershov Institute of Informatics Systems, Russian Academy of Sciences, Siberian Branch, Prosp. Acad. Lavrenteva 6, Novosibirsk 630090 Russia. E-mail: ressaure@gmail.com.

*** Институт систем информатики СО РАН им А.П. Ершова, просп. Академика Лаврентьева, Новосибирск 630090 Россия.
}

Key words: entomopathogenic ascomycetes, Russia, West Siberia, diversity.

Ключевые слова: энтомопатогенные аскомицеты, Россия, Западная Сибирь, разнообразие.

Abstract. The entomopathogenic fungus Ophiocordyceps variabilis (Petch) G.H. Sung, J.M. Sung, Hywel-Jones et Spatafora is recorded from Siberia for the first time. The fungus was found in the mixed forests of Novosibirsk city $\left(54.8^{\circ} \mathrm{N}, 83.1^{\circ} \mathrm{E}\right)$ and in the Yugansky Reserve (59.2$60.3^{\circ} \mathrm{N}, 73.5-74.0^{\circ} \mathrm{E}$ ) on larvae of Xylophagidae (Diptera) in dead fallen wood. The fungi were genotyped using $T E F-1 \alpha$ gene sequence analysis and they were 99-100\% identical to the North American O. variabilis.

Резюме. Впервые в Сибири обнаружен вид энтомопаразитического гриба Ophiocordyceps variabilis (Petch) G.H. Sung, J.M. Sung, Hywel-Jones et Spatafora. Грибы обнаружены в смешанных лесах окр. г. Новосибирск $\left(54,4^{\circ}\right.$ с.ш., $83,6^{\circ}$ в.д.) и в Юганском заповеднике $\left(59,2-60,3^{\circ}\right.$ с.ш. $73,5-74,0^{\circ}$ в.д) на личинках мух ксилофагид (Xylophagidae, Diptera) в валежной древесине. Анализ последовательностей региона $52 T E F-1 \alpha$ показал 99-100 \% сходство Сибирских изолятов $O$. variabilis с экземплярами из Северной Америки.

Entomopathogenic ascomycetes are natural resource for the development of bioinsecticidal and pharmacological products. The species diversity of these organisms in Russia, and especially in Siberia, is poorly studied. This lack of information is related to the locality of their distribution, which is caused by the continental climate and is not optimal for the development of these fungi. That have been sporadic studies of these fungi in Siberia [Ogarkov, Ogarkova, 2000; Gorbunova et al., 2011; Kryukov et al., 2011, 2018].

We found ascomycetes Ophiocordyceps variabilis in the territory of Novosibirsk Academic town and the Yugansky Reserve from 2009 to 2016. The morphological characteristics of the collected samples conformed to those previously described for this species [Beug et al., 2014] (Fig. 1). In Novosibirsk Academic Town, the fungi were found in July and August in mixed forest with a predominance of spruce, aspen, birch and pine in the overstory and Pteridium aquilinum (L.) Kuhn and Aegopodium L. in the grass layer. In the Yugansky Reserve, these ascomycetes were found in September in mature mixed coniferous forest with relatively old, falling aspen trees. The insects infected by the fungi were located in dead wood (Populus sp.) that was overgrown with mosses. The hosts of the fungi were xylophagid flies (Diptera, Xylophagidae).

The sample identification was carried out by sequencing the region of the gene for the elongation factor $(T E F-1 \alpha)$ [Sung et al., 2007]. The total DNA was isolated from fresh stromata. The isolation of the DNA, amplification and purification of the product were carried out as previously described [Kryukov et al., 2018]. The phylogenetic analysis was based on a comparison (700 bp) of the Siberian samples (Ak-2, Ak-4), a sample collected in the Far East (Obh) and sequences from 

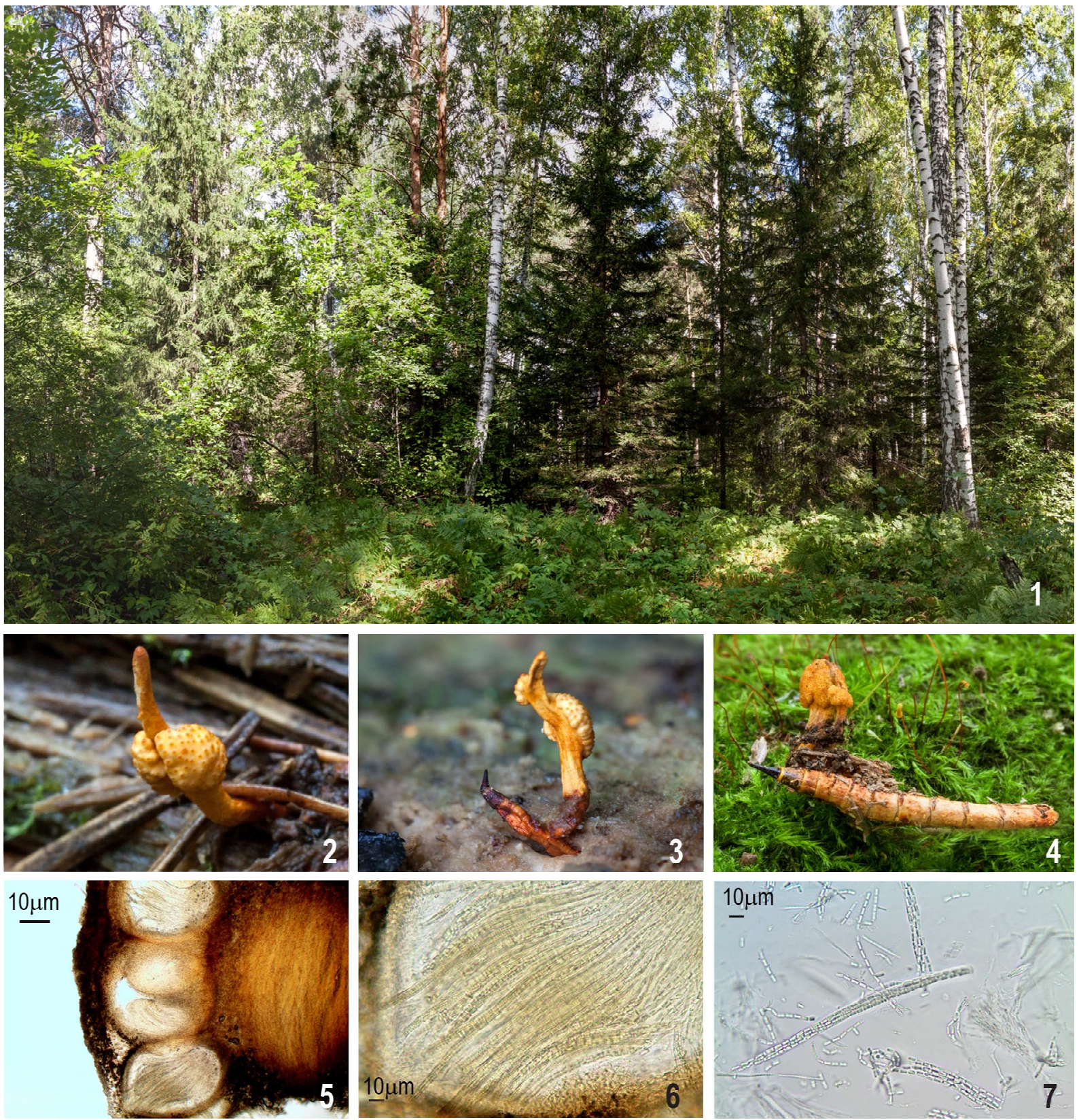

Fig. 1. Entomopathogenic fungus Ophiocordyceps variabilis. $1-$ habitat (Novosibirskaya Oblast), 2-4 - stromata, 5-6 perithecia with ascospores, 7 - ascospores. Photos by D.V. Ageev, and T.M. Bulyonkova.

Рис. 1. Энтомопатогенный гриб Opbiocordyceps variabilis. 1 - биоценоз (окр. г. Новосибирск), 2-4 - стромы, 5-6 перитеции с аскоспорами, 7 - аскоспоры. Фотографии А.В. Агеева и Т.М. Бульонковой.

GenBank. The Siberian and Far East samples were divided into two haplotypes with an identity of $99 \%$ (Fig. 2). The Siberian samples were $100 \%$ identical to the North American strain ARSEF 5365. The Far East sample was $99.39 \%$ identical to the strain OSC 111003 , which was also collected in North America [R. Kepler, personal communication].

O. variabilis was first described by Petch in 1937 as Cordyceps variabilis. The fungus is a highly specialized parasite of Xylophagidae [Hodge et al., 1998]. Previously, some authors indicated that the larvae of beetles were the hosts of this pathogen [Petch, 1937; Mains,
1958]. However, by checking collected samples, it was determined that the hosts are diptera larvae [Hodge et al., 1998]. The fungus anamorph was described by Hodge and coauthors [1998], and it was classified as Syngliocladium. The authors isolated this anamorph from both $O$. variabilis (C. variabilis) ascospores and from infected insects (Tetanops myopaeformis) collected in the field. However, this description was based only on morphocultural analysis. We were unable to isolate this fungus in a culture and obtain its anamorphic stage. Futher study be focused on interaction between $O$. variabilis and hosts. 


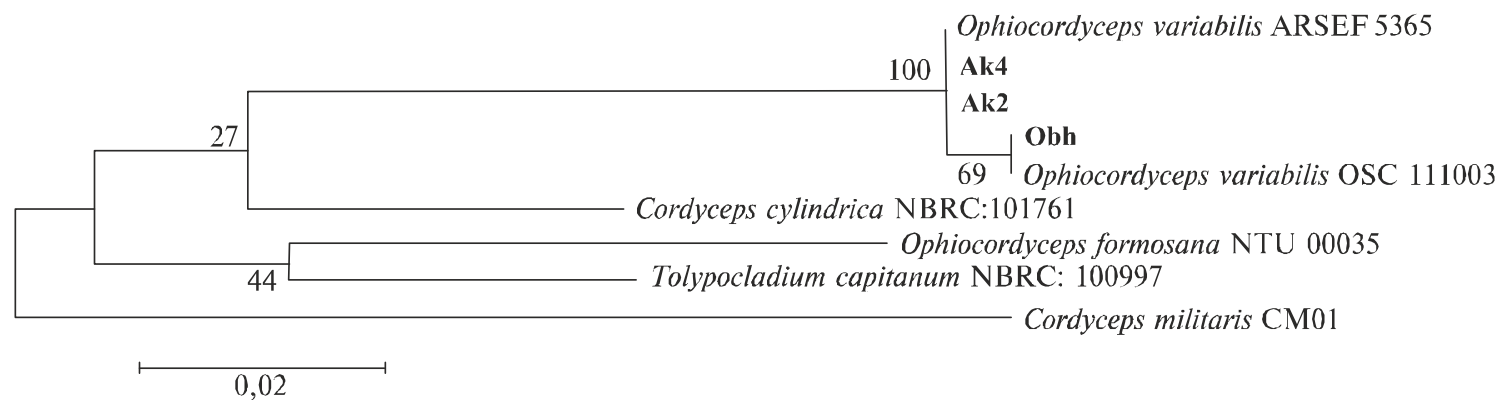

Fig. 2. Phylogenetic placement of Opbiocordyceps variabilis from Western Siberia (Ak-2 and Ak-4) and the Far East (Obh) based on partial elongation factor tef1a gene sequences. The maximum likelihood method, based on the Tamura-Nei model using the neighbor-join and BioNJ (MEGA 6 program) algorithms, was used. The number in the nodes is the value of the bootstrap support for the branch node. The isolates genotyped in the present study are in bold.

Рис. 2. Фимогенетическое положение Opbiocordyceps variabilis из Западной Сибири (Ak-2 и Ak-4) и Аальнего Востока (Obh), построенное на основе региона фактора элонгаџии (tef1a). Использован метод максимального правдоподобия на основе модели Tamura-Nei с использованием алгоритмов Neighbor-Join и BioNJ (программа MEGA 6). Число в узлах явмяется значением поддержки. Изоляты, генотипированные в настоящем исследовании, выделены жирным шрифтом.

Ophiocordyceps variabilis

(Petch) G.H. Sung, J.M. Sung,

Hywel-Jones et Spatafora, 2007

Material. Western Siberia, Novosibirsk, Academic Town, a forest-park zone near the main building of the Institute of Cytology and Genetics of the Siberian Branch of the Russian Academy of Sciences $\left(54^{\circ} 50.82^{\prime} \mathrm{N}, 8^{\circ} 6.12^{\prime}\right.$ E), 07.2009: 1 sample; 08.08.2011: 3 samples, T.M. Bulyonkova. Novosibirsk, Academic Town, the territory of the Botanical Garden of the SB RAS (54⒋98' N, 83⒎02' E), 13-15.08.2013: 12 samples, Ageev D.V., Kryukov V.Yu. Tyumen region, Yugansky Nature Reserve, Medvezhiy ugol Cordon, $\left(59^{\circ} 23.549^{\prime} \mathrm{N}, 74^{\circ} 0.666^{\prime} \mathrm{E}\right)$, 12.09.2012: 1 sample. Tyumen region, $10 \mathrm{~km} \mathrm{~W}$ of Ugut village, $\left(60^{\circ} 30.177^{\prime} \mathrm{N}, 73^{\circ} 54.77^{\prime} \mathrm{E}\right), 9.09 .2016$ : 1 sample, T.M. Bulyonkova.

Distribution. South America (Brazil), North America (USA, Canada) [Petch, 1937; Mains, 1958; Hodge et al., 1998]; China [Liang et al., 1995]; Africa (Congo) [Moureau, 1961]; Japan [Kobayasi, 1941]; Russia: Novgorod Region, [Popov, Arslanov, 2014], Primorye Territory [Borisov B.A., personal communication; presented data; Koval, 1974: described as Cordyceps corallomyces], Western Siberia [presented data].

\section{Acknowledgements}

This work was supported by grant No. MK6456.2018.11 from the President of the Russian Federation.

\section{References}

Beug M.W., Bessette A.E., Bessette A.R. 2014. Ascomycete fungi of North America. A mushroom reference guide. Austin: University of Texas Press. P.343-344.

Gorbunova I.A., Kryukov V.Yu., Zibzeev E.G. 2011. First records of the entomopathogenic fungus Ophiocordyceps gracilis (Ascomycota, Hypocreales) from Siberia // Evraziatskii Entomologicheskii Zhurnal (Euroasian entomological journal). Vol.10. No.1. P.P.17-18
Hodge K.T., Humber R.A., Wozniak C.A. 1998. Cordyceps variabilis and the genus Syngliocladium // Mycologia. Vol. 90. No.5. P.743-753.

Kobayasi Y. 1941. The genus Cordyceps and its allies // Science Reports of the Tokyo Bunrika Daigaku. Sect.B. Vol.84. No.5. P.53-260.

Koval' E.Z. 1974. Opredelitel' entomofil'nykh gribov SSSR. Kiev: Naukova Dumka. 258 p. [In Russian].

Kryukov V.Yu., Yaroslavtseva O.N., Lednev G.R., Borisov B.A. 2011. Local epizootics caused by teleomorphic cordycipitoid fungi (Ascomycota: Hypocreales) in populations of forest lepidopterans and sawflies of the summer-autumn complex in Siberia // Microbiology. Vol.80. No.2. P.286-296.

Kryukov V.Yu., Tomilova O.G., Yaroslavtseva O.N., Wen T.-C., Kryukova N.A., Polenogova O.V., Tokarev Yu.S., Glupov V.V. 2018. Temperature adaptations of Cordyceps militaris, impact of host thermal biology and immunity on mycosis development // Fungal Ecology. Vol.35. P.98-107.

Liang, Z.-Q. 1991. Verification and identification of the anamorph of Cordyceps pruinosa Petch // Acta Mycologica Sinica. Vol.10. P.104-107.

Moureau J. 1961. Nouveaux Cordyceps du Congo // Lejeunia Mem. Vol.15. P.1-38.

Ogarkov B.N. Ogarkova G.R. 2000.Entomopathogenic Fungi of East Siberia, Irkutsk: Irkutsk Univ. 134 p. [In Russian].

Petch T. 1937. Notes on entomogenous fungi // Transactions of the British Mycological Society. Vol.21. P.34-67.

Mains E.B. 1958. North American Entomogenous Species of Cordyceps // Mycologia. Vol.50. No.2. P.169-222.

Popov E.S., Arslanov S.N. 2014. New data on ascomycetes of the Novgorod region // Novosti sistematiki nizshikh rasteniy. Vol.48. P.204-218. [In Russian]

Sung G.H., Sung J.M., Hywel-Jones N.L., Spatafora J.W. 2007. A multi-gene phylogeny of Clavicipitaceae (Ascomycota, Fungi): identification of localized incongruence using a combinational bootstrap approach // Molecular Phylogenetics and Evolution. Vol.44. No.3. P.1204-1223.

Sung G.-H., Hywel-Jones N.L., Sung J.-M., Luangsa-ard J.J., Shrestha B., Spatafora J.W. 2007. Phylogenetic classification of Cordyceps and the clavicipitaceous fungi // Studies in Mycology. Vol.57. P.5-59. 